\title{
KEMAMPUAN PRIOR OPINION MEMODERASI PENGARUH PROFITABILITAS, LEVERAGE, LIKUIDITAS, PERTUMBUHAN PERUSAHAAN DAN RASIO AKTIVITAS TERHADAP OPINI AUDIT GOING CONCERN
}

\author{
Made Ayu Jayanti Prita Utami ${ }^{1}$ \\ Maria M. Ratna Sari ${ }^{2}$ \\ Ida Bagus Putra Astika ${ }^{3}$
${ }^{1,2,3}$ Fakultas Ekonomi dan Bisnis Universitas Udayana, Bali, Indonesia e-mail: jayanti.pritautami@gmail.com

\begin{abstract}
ABSTRAK
Penelitian ini bertujuan untuk memperoleh bukti kemampuan prior opinion dalam memoderasi pengaruh profitabilitas, leverage, likuiditas, pertumbuhan perusahaan dan rasio aktivitas terhadap pemberian opini audit going concern. Perbedaan hasil penelitian ini dengan penelitian yang lain dapat diselesaikan melalui pendekatan kontinjensi, dimana variabel prior opinion diduga memoderasi pengaruh rasio keuangan seperti profitabilitas, leverage, likuiditas, pertumbuhan perusahaan dan rasio aktivitas terhadap pemberian opini audit going concern. Jumlah sampel dalam penelitian adalah 438 sampel yang dipilih dengan teknik purposive sampling dari seluruh perusahaan manufaktur yang terdaftar di Bursa Efek Indonesia periode 2010-2015. Penelitian ini dianalisis dengan menggunakan analisis regresi logistik. Hasil yang diperoleh adalah prior opinion memperlemah pengaruh profitabilitas yang diproksikan dengan ROA pada pemberian opini going concern, namun prior opinion tidak memoderasi pengaruh leverage, likuiditas, pertumbuhan perusahaan dan rasio aktivitas pada pemberian opini audit going concern.
\end{abstract}

Kata kunci: prior opinion, opini audit going concern, rasio keuangan, pertumbuhan perusahaan, rasio aktivitas.

\begin{abstract}
This study aimed to get evidence of prior opinions in its ability to moderate the effect of profitability, leverage, liquidity, company growth and activity ratios on going concern audit opinion. The difference results of these studies with the other studies can be completed through a contingency approach, in which variables prior opinion allegedly moderating influence of financial ratios such as profitability, leverage, liquidity, growth and activity ratios to administration going concern audit opinion. The number of samples in this study were 438 samples selected by purposive sampling manufacturing companies listed in Indonesia Stock Exchange 2010-2015 period. Data analysis technique used is the logistic regression analysis. The results obtained are prior opinion weaken the influence of profitability wich is proxied by ROA on going concern audit opinions, but prior opinion does not moderate the effect of leverage, liquidity, growth and activity ratio on going concern audit opinion.
\end{abstract}

Keywords: prior opinion, going concern audit opinion, finance ratio, company growth, activity ratio. 


\section{PENDAHULUAN}

Auditor memiliki peranan penting untuk memediasi antara kepentingan investor dan perusahaan. Auditor melakukan penilaian atas kondisi perusahaan yang akan menjadi sumber infomasi bagi investor untuk menentukan keputusan. Hasil penilaian auditor yang diungkapkan melalui opini audit akan membuat pengguna menjadi semakin percaya pada laporan data yang terdapat di dalam laporan keuangan perusahaan auditan.

Setelah auditor independen melakukan tugas pengauditan atas laporan keuangan suatu perusahaan, maka auditor independen tersebut akan memberikan pendapat atau opini yang sesuai dengan kondisi sebenarnya dari perusahaan yang diauditnya. Jika dalam proses identifikasi informasi mengenai kondisi perusahaan auditor tidak menemukan adanya salah saji material yang menyebabkan kesangsian besar terhadap kemampuan entitas untuk mempertahankan kelangsungan hidupnya, maka auditor akan memberikan opini audit non going concern dan opini audit going concern akan diberikan kepada perusahaan yang oleh auditor diragukan kemampuannya dalam menjaga kelangsungan usaha perusahaan (Sari, 2012).

Going concern adalah kemampuan satuan usaha dalam mempertahankan kelangsungan hidupnya selama periode waktu pantas, yaitu tidak lebih dari satu tahun sejak tanggal laporan keuangan (Standar Profesional Akuntan Publik, 2011). Going concern disebut juga sebagai kontinuitas akuntansi yang memperkirakan suatu bisnis akan terus berlanjut 
dalam waktu tidak terbatas (Syahrul,2000). Asumsi going concern memiliki arti bahwa suatu badan usaha dianggap akan mampu mempertahankan kegiatan usahanya dalam jangka waktu panjang dan tidak akan dilikuidasi dalam jangka waktu yang pendek.

Opini audit modifikasi mengenai going concern merupakan opini audit yang dalam pertimbangan auditor terdapat ketidakmampuan atau ketidakpastian signifikan atas kelangsungan hidup perusahaan dalam menjalankan operasinya pada kurun waktu yang pantas, tidak lebih dari satu tahun sejak tanggal laporan keuangan yang sedang diaudit (SPAP, 2011). Auditor bertanggung jawab untuk menilai apakah terdapat kesangsian besar terhadap kemampuan perusahaan dalam mempertahankan kelangsungan hidupnya (going concern) dalam periode waktu tidak lebih dari satu tahun sejak tanggal laporan audit. American Institute of Certified Public Accountants (1988 dalam Praptitorini, 2007) menjelaskan saat ini, auditor harus mengemukakan secara eksplisit apakah perusahaan klien akan dapat mempertahankan kelangsungan hidupnya sampai setahun kemudian setelah pelaporan. O'Reilly (2010) memberikan asumsi dasar dari opini audit going concern seharusnya bermanfaat untuk investor sebagai sinyal negatif tentang keberlangsungan hidup suatu entitas.

Pemberian status going concern bukanlah suatu tugas yang mudah karena berkaitan erat dengan reputasi auditor. Penghakiman terhadap akuntan publik sering dilakukan, baik oleh masyarakat maupun pemerintah dengan melihat kondisi bangkrut tidaknya perusahaan yang diaudit (Ginting 
Prita Utami., Maria M. Ratna Sari, dan I. B. Putra Astika. Kemampuan Prior Opinion....

dan Suryana, 2014). Saat ini tanggung jawab auditor tidak hanya sebatas memeriksa laporan keuangan atau mendeteksi kecurangan, tetapi juga menilai kemampuan perusahaan dalam mempertahankan kelangsungan hidupnya dikarenakan bahwa kemungkinan perusahaan mengalami kegagalan dalam mempertahankan hidupnya akan selalu ada, sehingga auditor dalam melaksanakan proses audit harus dapat melihat tingkat kegagalan perusahaan dalam mempertahankan kelangsungan hidupnya. Sulitnya memprediksi kelangsungan hidup suatu perusahaan menyebabkan banyak auditor yang mengalami dilema moral dan etika dalam memberikan opini going concern (Januarti, 2008).

Penerbitan opini audit going concern akan menyebabkan auditee merasa tidak nyaman sehingga akan ada upaya untuk membelokkan opini audit going concern tersebut. Auditee akan berusaha untuk membujuk auditor untuk melakukan penilaian ulang dari segala aspek seperti membuat kembali laporan keuangan yang baru demi tercapainya pemenuhan standar audit perusahaan. Kejadian tersebut tentunya akan mengakibatkan audit delay yaitu lamanya waktu yang diperlukan untuk mengaudit perusahaan yang dinilai sejak dari waktu penutupan buku sampai waktu terbit laporan dan akhirnya akan berpengaruh kepada ketepatan informasi yang dipublikasikan (Andi Kartika, 2009). Dampak negatif dari fenomena audit delay ini berkaitan dengan ketepatan waktu (timeliness) auditee dalam mengumumkan laporan keuangannya kepada masyarakat dan Otoritas Jasa Keuangan (OJK). 
Profitabilitas yaitu bagaimana perusahaan menghasilkan laba yang diperoleh dari kegiatan operasional perusahaan, jumlah asset, maupun modal yang dimiliki sendiri. Penelitian Chen \& Church (1992), Behn et al. (2001), dan Widyantari (2011) mengatakan bahwa rasio profitabilitas memiliki pengaruh negatif signifikan di dalam memprediksi pembentukan keputusan opini audit going concern. Namun penelitian Hani dkk. (2003), Rahayu (2007), Januarti dan Fitrianasari (2008), Juanidi (2010) menyatakan tidak ada pengaruh antara rasio profitabilitas dengan opini audit going concern.

Leverage merupakan kemampuan perusahaan untuk melunasi kewajibannya (jangka panjang maupun jangka pendek). Kinerja keuangan perusahaan yang semakin buruk akan ditunjukkan oleh rasio leverage yang tinggi dan dapat membuat keberlanjutan usaha perusahaan menjadi semakin tidak menentu. Perusahaan yang memiliki kewajiban lebih besar dari jumlah aktivanya akan cenderung riskan untuk bangkrut (Chen dan Church, 1992).

Menurut Brigham dan Houston (2010:134) likuiditas bisa dihitung dengan current ratio (rasio lancar). Rasio likuiditas perusahaan biasanya sering dinilai menggunakan current ratio dimana aktiva lancar dibandingkan dengan kewajiban lancar. Dalam hubungannya dengan likuiditas, semakin sedikit nilai current ratio menggambarkan semakin sedikit pula kemampuan perusahaan dalam menutupi kewajiban jangka pendeknya dan sebaliknya semakin tinggi tingkat likuiditasnya, maka perusahaan dirasa mampu untuk menutupi kewajiban jangka pendeknya 
sehingga bisa terhindar dari pemberian opini audit going concern oleh auditor.

Pertumbuhan perusahaan menggambarkan bagaimana sebuah perusahaan mampu untuk meningkatkan ukuran perusahaan. Pertumbuhan perusahaan yang cepat akan semakin membutuhkan banyak dana untuk melakukan ekspansi. Kristiana (2012) dalam penelitiannya pada sektor industri manufaktur meneliti bahwa pertumbuhan perusahaan secara signifikan mempengaruhi pemberian opini audit going concern secara signifikan. Sedangkan hasil penelitian Nursasi dan Maria (2013) mengatakan bahwa pertumbuhan perusahaan berpengaruh negatif pada pemberian opini audit going concern.

Rasio aktivitas merupakan salah satu rasio keuangan yang bisa digunakan sebagai salah satu tolak ukur dalam pengukuran kinerja perusahaan. Rasio ini mengukur keefektifan serta keefisienan perusahaan dalam melakukan pengelolaan aktiva. Dari pengujian yang dilakukan oleh Januarti dan Fitrianasari (2008) terhadap rasio aktivitas, diperoleh suatu bukti bahwa rasio aktivitas tidak memiliki pengaruh terhadap pemberian opini audit dengan paragraf going concern.

Salah satu faktor lain yang menjadi pertimbangan auditor dalam pemberian opini going concern adalah prior opinion. Auditor dalam memberikan opini audit going concern di tahun berjalan bisa dipengaruhi oleh opini audit going concern yang diterima auditee pada tahun sebelumnya (prior opinion). Hal ini terjadi jika perusahaan tidak 
menunjukkan adanya upaya untuk melakukan perbaikan terhadap kondisi keuangan perusahaan.

Penelitian ini berbeda dengan penelitian sebelumnya dimana peneliti menempatkan prior opinion sebagai pemoderasi yang mempengaruhi pengaruh profitabilitas, leverage, dan likuiditas pada pemberian opini audit going concern dengan menambahkan satu variabel baru sebagai variabel independen yaitu rasio aktivitas serta menggunakan data yang lebih besar dari penelitian sebelumnya yaitu dari tahun 2010-2015.

Kegunaan dari penelitian ini dapat memberikan manfaat teoritis untuk memperjelas teori normatif mengenai teori agensi serta teori empiris dari peneliti-peneliti sebelumnya serta bisa menjadi referensi penelitian lebih lanjut yang berkaitan dengan prior opinion yang secara konseptual dapat mempengaruhi hubungan antara profitabilitas, leverage, likuiditas, pertumbuhan perusahaan dan rasio aktivitas pada pemberian opini going concern.

Teori keagenan (Agency theory) memberikan gambaran keterkaitan antara prinsipal dan agen dimana prinsipal (shareholder/ pemegang saham bertanggung jawab atas pembuatan keputusan kepada agen (manajemen) (Jensen dan Meckling, 1976). Keterkaitan yang terjadi yaitu agen/ manajemen berperan didalam mengelola operasional perusahaan hingga menghasilkan laporan keuangan perusahaan yang merupakan tugas manajemen dimana laporan keuangan ini akan digunakan untuk pengambilan keputusan. Dikatakan sebagai dasar pengambilan keputusan 
karena dari laporan keuangan yang telah diaudit, untuk selanjutnya akan dipublikasikan sehingga mampu mempengaruhi investor dalam hal pengambilan keputusan. Jika perusahaan memperoleh opini audit going concern, maka tentu saja investor akan mengurungkan niatnya untuk berinvestasi sehingga terjadi penurunan harga saham perusahaan, sedangkan jika perusahaan memperoleh opini audit non going concern, maka investor akan berinvestasi dan berdampak pada peningkatan harga saham perusahaan.

Penelitian Widyantari (2011) membuktikan pengaruh profitabilitas yang signifikan pada opini audit going concern. Nilai profitabilitas yang cukup tinggi tidak bisa menjamin perusahaan akan terhindar dari opini audit going concern disebabkan oleh adanya faktor prior opinion yang bisa dijadikan dasar pertimbangan kembali untuk mengeluarkan opini audit going concern di tahun selanjutnya.

Berdasarkan studi-studi tersebut dan alur berpikir jika opini audit going concern yang didasarkan pada rasio profitabilitas juga dipengaruhi oleh opini yang diberikan sebelumnya, jadi dapat disusun hipotesis sebagai berikut.

$\mathrm{H}_{1}$ : Prior opinion memperlemah pengaruh profitabilitas pada opini audit going concern.

Rasio leverage digunakan untuk menilai perusahaan untuk memenuhi kewajiban jangka pendek maupun jangka panjang dengan memakai debt ratio. Nilai rasio leverage yang tinggi bisa berakibat buruk. Jika nilai rasio leverage tinggi maka kinerja keuangan perusahaan akan 
terlihat semakin tidak baik dan bisa mengakibatkan ketidakpastian terhadap kelangsungan hidup usaha perusahaan. Hal inilah yang menjadi penyebab perusahaan memiliki peluang untuk memperoleh opini audit going concern. Sejalan dengan prior opinion, menurut Kartika (2012) jika auditor menerbitkan opini audit going concern tahun sebelumnya maka semakin besar pula kemungkinan perusahaan memperoleh kembali opini audit going concern di tahun berjalan. Dari penjelasan diatas, maka hipotesis yang dapat disusun sebagai berikut.

$\mathrm{H} 2$ : Prior opinion memperkuat pengaruh leverage pada opini audit going concern.

Likuiditas yaitu penggunaan aktiva lancar perusahaan untuk memenuhi kewajiban jangka pendeknya. Auditor akan meragukan kelangsungan hidup usaha perusahaan apabila nilai rasio likuiditasnya rendah atau secara tidak langsung kemampuan perusahaan untuk melaksanakan kewajibannya adalah rendah. Penelitian sebelumnya, Sari (2012) dan Hany dkk (2003) likuiditas berpengaruh pada opini audit going concern. Oleh karena itu, apabila nilai likuiditas sebuah perusahaan tinggi maka perusahaan dianggap mampu memenuhi kewajiban jangka pendeknya serta akan terhindar dari pemberian opini going concern.

Jika likuiditas perusahaan tinggi tidak bisa dipastikan perusahaan akan terhindar dari pemberian opini going concern karena adanya prior opinion yang dapat dijadikan dasar pertimbangan bagi auditor untuk memberikan kembali opini audit going concern pada tahun berikutnya. Berdasarkan penjelasan tersebut, maka dapat disusun hipotesis berikut. 
$\mathrm{H}_{3}$ : Prior opinion memperlemah pengaruh likuiditas pada opini audit going concern.

Pertumbuhan perusahaan diproksikan dengan menggunakan rasio pertumbuhan penjualan. Rasio pertumbuhan penjualan menggambarkan bagaimana usaha perusahaan dalam mendongkrak nilai penjualannya serta mempertahankan tingkat penjualannya dalam kondisi persaingan yang semakin ketat. Pertumbuhan perusahaan yang memiliki penjualan yang lebih tinggi dibandingkan dengan kenaikan biaya akan mengakibatkan kenaikan laba perusahaan.

Trend penjualan yang meningkat menggambarkan kinerja manajemen yang baik. Hal ini akan menurunkan resiko penerimaan opini audit going concern. Sementara sales growth ratio yang negatif menggambarkan perusahaan tidak mampu untuk mempertahankan kelangsungan usaha di tengah situasi persaingan yang cukup ketat. Hal tersebut memberikan gambaran bahwa perusahaan tidak berkembang dan mungkin akan mengalami defisit laba serta berpotensi memperoleh pemberian opini audit going concern.

Tingkat pertumbuhan perusahaan yang positif tidak bisa menjadi patokan akan terhindar dari opini audit going concern karena adanya faktor prior opinion yang bisa dijadikan dasar pertimbangan penting bagi auditor untuk memberikan kembali opini audit going concern pada tahun berikutnya. Berdasarkan landasan teori tersebut, maka disusun hipotesis sebagai berikut. 
H4 : Prior opinion memperlemah pengaruh pertumbuhan perusahaan pada opini audit going concern.

Rasio aktivitas dalam penelitian ini diproksikan dengan menggunakan total assets turn over (TAT). Total asset turn over adalah rasio aktivitas yang digunakan untuk menilai sejauh mana efektivitas perusahaan didalam menngelola sumber dayanya yang berupa asset. Semakin tinggi tingkat rasio ini maka semakin efisien pula penggunaan aset dan semakin cepat pula pengembalian dana dalam bentuk kas (Abdul Halim, 2007).

Namun tingkat rasio aktivitas yang tinggi belum bisa dipastikan akan terhindar dari pemberian opini audit going concern disebabkan karena adanya faktor prior opinion yang dijadikan dasar pertimbangan penting bagi auditor untuk memberikan kembali opini audit going concern kepada perusahaan di tahun berikutnya. Berdasarkan landasan teori tersebut, maka disusun hipotesis sebagai berikut.

H5 : Prior opinion memperlemah pengaruh rasio aktivitas pada opini audit going concern.

\section{METODE PENELITIAN}

Ruang lingkup penelitian ini adalah auditing yang menganalisis prior opinion sebagai pemoderasi pengaruh profitabilitas, leverage, likuiditas, pertumbuhan perusahaan dan rasio aktivitas pada pemberian opini going concern. Objek dalam artikel menggunakan salah satu industri yang cukup besar yaitu 
Prita Utami., Maria M. Ratna Sari, dan I. B. Putra Astika. Kemampuan Prior Opinion....

manufaktur yang listing di BEI periode 2010-2015. Data kuantitatif yang digunakan meliputi data keuangan yang diambil dari laporan keuangan auditan perusahaan tahun 2010-2015.

Variabel yang dianalisis diantaranya adalah opini going concern (GCO), profitabilitas (ROA), leverage (DAR), likuiditas (LIK), pertumbuhan perusahaan (PP), rasio aktivitas (TAT) dan prior opinion (PO), yang dijelaskan sebagai berikut :

1) Audit Going Concern adalah opini yang diterbitkan auditor mengenai pertimbangan terhadap ketidakpastian yang cukup signifikan terhadap kelangsungan usaha perusahaan didalam menjalankan kegiatan usahanya pada masa mendatang, Rudyawan (2008). Variabel dummy digunakan sebagai alat ukur dalam memberi opini audit going concern. Perusahaan yang memperoleh opini audit going concern diberikan nilai 1, sedangkan perusahaan yang tidak memperoleh opini going concern diberikan nilai 0 (Fadilah, 2013).

2) Rasio profitabilitas yang diproksikan dengan menggunakan perhitungan ROA yang dihitung menggunakan rumus :

$$
\text { ROA }=\frac{\text { Laba/Rugi Setelah Pajak }}{\text { Total Aset }}
$$

3) Rasio leverage diproksikan dengan debt to asset ratio yang diukur dengan menggunakan rumus:

$$
\mathrm{DAR}=\frac{\text { Total Kewajiban }}{\text { Total Aset }}
$$


4) Rasio likuiditas menggunakan perhitungan Current Ratio yang dihitung dengan rumus:

$$
\text { Current Ratio }=\frac{\text { Aset Lancar }}{\text { Kewajiban Lancar }}
$$

5) Pertumbuhan perusahaan diperoleh dengan menghitung sales growth ratio yang dihitung dengan menggunakan rumus :

$$
\text { Pertumbuhan Perusahaan }=\frac{\text { Penjualan Bersih }_{\mathrm{t}}-\text { Penjualan Bersih }_{\mathrm{t}-1}}{\text { Penjualan Bersih }_{\mathrm{t}-1}}
$$

6) Rasio aktivitas diproksikan dengan menggunakan total asset turnover (TAT) yang dihitung dengan rumus sebagai berikut :

$$
\text { Total Asset Turnover }=\frac{\text { Laba Bersih }}{\text { Pendapatan Operasional }}
$$

7) Prior opinion merupakan opini audit going concern yang diperoleh oleh auditee pada tahun sebelumnya. Kategori perusahaan yang memperoleh opini going concern pada tahun sebelumnya diberikan nilai 1 dan sebaliknya, yang memperoleh opini non going concern pada tahun sebelumnya diberikan nilai 0 .

Sampel pada penelitian ini yaitu perusahaan manufaktur yang terdaftar di BEI pada periode 2010-2015. Sektor manufaktur dipilih karena memiliki emiten terbanyak dibandingkan dengan jenis industri lainnya. Selain itu alasan menggunakan industri manufaktur karena meningkatnya currency disaat industri manufaktur memiliki hutang luar negeri menyebabkan kemungkinan industri manufaktur sulit meningkatkan labanya atau merugi sehingga mendapatkan opini going concern. 
Prita Utami., Maria M. Ratna Sari, dan I. B. Putra Astika. Kemampuan Prior Opinion....

Tabel 1 menjelaskan bahwa dari 142 total perusahaan manufaktur yang terdaftar di PT Bursa Efek Indonesia dari tahun 2010-2015, terdapat perusahaan yang delisting sebanyak 41 perusahaan, kemudian terdapat perusahaan yang tidak mempublikasikan laporan tahunannya di tahun pengamatan sehingga 12 perusahaan dikeluarkan dari sampel dan 16 perusahaan yang ternyata tidak menggunakan rupiah sebagai mata uang pelaporannya juga dikeluarkan dari sampel. Total sampel perusahaan yang digunakan pada penelitian ini menjadi 73 perusahaan sampel dengan periode amatan 6 tahun serta 438 data observasi selama periode pengamatan.

Data kemudian dianalisis dengan pendekatan deskriptif untuk memperoleh gambaran mengenai kondisi data, serta hipotesis diuji menggunakan metode Moderated Regression Analysis (MRA) dengan pendekatan regresi logistik karena variabel dependennya bersifat kategorikal yaitu menerima opini going concern dan opini non going concern. Model MRA yang digunakan adalah sebagai berikut:

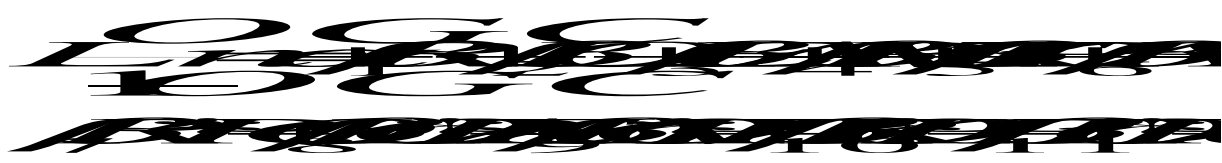

Keterangan:

OGC : Opini Audit Going concern ( 1 = opini audit going concern dan $0=$ opini audit non going concern).

A : Konstanta

$\beta_{1}-\beta_{11} \quad$ : Koefisien Regresi

ROA : Return On Asset (laba rugi bersih : rata-rata total asset)

LEV : Leverage ( total kewajiban : total asset)

LIK : Likuiditas ( aktiva lancar : kewajiban lancar)

PP : Pertumbuhan Perusahaan ((penjualan bersih $_{t}-$ penjualan bersih $_{\mathrm{t}-1) \text { : }}$ penjualan bersih $_{\mathrm{t}-1)}$

TAT : Total Asset Turnover (laba bersih : pendapatan operasional)

PO : Prior Opinion (kategori 1 bila opini audit going concern, 0 bila 


$\begin{array}{ll} & \text { bukan opini audit going concern ) } \\ \text { ROA*PO } & \text { : Interaksi antara prior opinion dengan Return On Asset } \\ \text { LEV*PO } & \text { : Interaksi antara prior opinion dengan Leverage } \\ \text { LIK*PO } & \text { : Interaksi antara prior opinion dengan Likuiditas } \\ \text { PP*PO } & \text { : Interaksi antara prior opinion dengan Pertumbuhan Perusahaan } \\ \text { TAT*PO } & \text { : Interaksi antara prior opinion dengan Total Asset Turnover } \\ \text { e } & \text { : error }\end{array}$

\section{HASIL DAN PEMBAHASAN}

\section{Statistik Deskriptif}

Statistik deskriptif menunjukkan mengenai kondisi data penelitian. Kondisi data dapat memberikan keterangan melalui keterangan umum. Rata-rata, nilai maksimum,serta nilai minimum merupakan bagian dari statistik deskriptif. Adapun hasilnya ditampilkan dalam tabel berikut .

Tabel 1.

\section{Statistik Deskriptif}

\begin{tabular}{lrrrrr}
\hline & N & Minimum & Maximum & Mean & Std. Deviation \\
\hline OGC & 438 & 0.00 & 1.00 & .1050 & .30693 \\
ROA & 438 & -61.93 & 74.84 & 7.8979 & 12.55477 \\
LEV & 438 & .04 & 8.48 & .5093 & .50709 \\
LIK & 438 & 2.05 & 46498.44 & 477.7753 & 2588.89575 \\
PP & 438 & -.93 & 7.91 & .1570 & .61014 \\
TAT & 438 & .02 & 6.85 & 1.1816 & .61245 \\
PO & 438 & 0.00 & 1.00 & .0890 & .28513 \\
ROA_PO & 438 & -61.93 & 49.23 & -.2228 & 4.29465 \\
LEV_PO & 438 & 0.00 & 8.48 & .0877 & .49474 \\
LIK_PO & 438 & 0.00 & 1334.92 & 28.3833 & 143.91710 \\
PP_PO & 438 & -.77 & .76 & -.0026 & .09244 \\
TAT_PO & 438 & 0.00 & 3.11 & .0720 & .27992 \\
\hline
\end{tabular}

Sumber : Hasil Penelitian

\section{Analisis Regresi Logistik}

Analisis regresi logistik tahapan pertama dilakukan dengan melakukan pengujikan kelayakan model serta fitnya (overall model fit test) untuk mengetahui 
Prita Utami., Maria M. Ratna Sari, dan I. B. Putra Astika. Kemampuan Prior Opinion....

ada atau tidaknya perubahan model dengan keberadaan variabel bebas ke dalam model. Adapun hasilnya adalah sebagai berikut:

Tabel 2.

Hasil Pengujian Model Fit

\begin{tabular}{llrr}
\hline \multirow{2}{*}{ Iteration } & \multicolumn{2}{c}{}
\end{tabular}$} &{\multicolumn{2}{c}{\text { Coefficients }}\text { Coefficients }} \\
{$\cline { 2 - 4 }$} &{1} &{309.430} &{\multicolumn{1}{c}{\text { Constant }}\text { Constant }} \\
{$\cline { 2 - 4 }$} &{2} &{294.727} &{-1.580} \\
{$\cline { 2 - 4 }$} &{3} &{294.320} &{-2.044} \\
{$\cline { 2 - 4 }$} &{4} &{294.319} &{-2.139} \\
{$\cline { 2 - 4 }$} &{5} &{294.319} &{-2.143} \\
{\hline} \end{array}$

Sumber : Hasil Penelitian

Tabel 3.

Hasil Pengujian Keseluruhan Model (Overall Model Fit Test)

\begin{tabular}{|c|c|c|c|c|c|c|c|c|c|c|c|c|c|c|}
\hline \multirow{2}{*}{\multicolumn{2}{|c|}{ Iteration }} & \multirow{2}{*}{$\begin{array}{c}-2 \text { Log } \\
\text { likeliho } \\
\text { od }\end{array}$} & \multicolumn{12}{|c|}{ Coefficients } \\
\hline & & & Constant & ROA & LEV & LIK & PP & TAT & PO & $\begin{array}{c}\mathrm{ROA}_{-} \\
\text {PO }\end{array}$ & $\begin{array}{c}\text { LEV_- }_{\text {PO }} \\
\text { PO }\end{array}$ & $\begin{array}{r}\text { LIK } \\
\text { PO }\end{array}$ & PP_PO & $\begin{array}{c}\text { TAT }_{-} \\
\text {PO }\end{array}$ \\
\hline \multirow[t]{8}{*}{ Step 1} & 1 & 243.339 & -1.779 & -.014 & .594 & .000 & .162 & -.132 & 1.292 & -.054 & -.302 & .000 & -1.252 & .185 \\
\hline & 2 & 193.524 & -2.310 & -.046 & .892 & .000 & .229 & -.224 & 1.432 & -.148 & -.604 & .000 & -1.395 & .280 \\
\hline & 3 & 175.136 & -2.217 & -.099 & .880 & .000 & .217 & -.379 & .842 & -.269 & -.855 & .000 & -1.451 & .669 \\
\hline & 4 & 170.254 & -1.995 & -.135 & .883 & .000 & .123 & -.620 & .133 & -.403 & -1.142 & .001 & -1.535 & 1.184 \\
\hline & 5 & 169.706 & -1.921 & -.149 & .880 & .000 & .085 & -.700 & -.195 & -.494 & -1.275 & .002 & -1.587 & 1.420 \\
\hline & 6 & 169.691 & -1.917 & -.150 & .879 & .000 & .083 & -.705 & -.254 & -.518 & -1.302 & .002 & -1.602 & 1.466 \\
\hline & 7 & 169.691 & -1.917 & -.150 & .879 & .000 & .083 & -.705 & -.256 & -.519 & -1.303 & .002 & -1.603 & 1.468 \\
\hline & 8 & 169.691 & -1.917 & -.150 & .879 & .000 & .083 & -.705 & -.256 & -.519 & -1.303 & .002 & -1.603 & 1.468 \\
\hline
\end{tabular}

Sumber : Hasil penelitian

Tabel 3 menunjukkan nilai dari -2 Log Likelihood sebesar 169,691. Hal ini berarti terdapat penurunan nilai-2 Log Likelihood sebesar 124,628 setelah keseluruhan variabel bebas dimasukkan ke dalam model. Penurunan nilai ini 
menggambarkan model yang lebih baik serta fit dengan data setelah ditambahkan variabel bebas ke dalam model.

Kelayakan model regresi logistik diuji agar dapat memberikan gambaran jika salah satu variabel bebas memiliki pengaruh yang melebihi taraf nyata yang ditentukan. Adapun hasil pengujiannya disajikan dalam Tabel 4.

Tabel 4.

Hasil Pengujian Kelayakan Model Regresi

\begin{tabular}{clrrr}
\hline & & & & \\
& & & & \\
Step 1 & Step & 124.629 & & Sig. \\
& Block & 124.629 & 11 & .000 \\
\cline { 2 - 5 } & Model & 124.629 & 11 & .000 \\
\hline \multirow{2}{*}{ Sumber $:$ Hasil penelitian } & & & & .000 \\
\hline
\end{tabular}

Pengujian multikolinearitas berguna dalam melihat besarnya hubungan antara variabel independen di dalam penelitian. Matrik hubungan antara variabel indepen digunakan untuk melakukan pengujian multikolinearitas dalam model ini. Regresi yang dapat digunakan adalah yang tidak ada kaitan antara variabel bebas atau independen. Adapun hasilnya disajikan oleh tabel berikut:

Tabel 5.

Hasil Pengujian Multikolinearitas

\begin{tabular}{|c|c|c|c|c|c|c|c|c|c|c|c|c|c|}
\hline & & $\begin{array}{c}\text { Const } \\
\text { ant }\end{array}$ & ROA & LEV & LIK & PP & TAT & PO & $\begin{array}{c}\text { ROA }_{-} \\
\text {PO }\end{array}$ & $\begin{array}{c}\text { LEV }_{-} \\
\text {PO }\end{array}$ & $\begin{array}{c}\text { LIK_ } \\
\text { PO }\end{array}$ & $\begin{array}{c}\text { PP_P } \\
\mathbf{O}\end{array}$ & $\begin{array}{c}\text { TAT_ }_{-} \\
\text {PO }\end{array}$ \\
\hline \multirow{10}{*}{$\begin{array}{l}\text { Step } \\
1\end{array}$} & Constant & 1.000 & -.084 & -.559 & -.270 & -.081 & -.780 & -.433 & .014 & .410 & .007 & .011 & .328 \\
\hline & ROA & -.084 & 1.000 & .201 & .070 & .166 & -.136 & .036 & -.162 & -.148 & -.002 & -.023 & .057 \\
\hline & LEV & -.559 & .201 & 1.000 & .203 & -.202 & .041 & .242 & -.033 & -.735 & -.005 & .027 & -.017 \\
\hline & LIK & -.270 & .070 & .203 & 1.000 & .031 & .127 & .117 & -.011 & -.149 & -.026 & -.004 & -.053 \\
\hline & PP & -.081 & .166 & -.202 & .031 & 1.000 & .116 & .035 & -.027 & .148 & -.001 & -.136 & -.049 \\
\hline & TAT & -.780 & -.136 & .041 & .127 & .116 & 1.000 & .338 & .022 & -.030 & -.003 & -.016 & -.421 \\
\hline & $\mathrm{PO}$ & -.433 & .036 & .242 & .117 & .035 & .338 & 1.000 & .372 & -.141 & -.311 & .396 & -.816 \\
\hline & ROA_PO & .014 & -.162 & -.033 & -.011 & -.027 & .022 & .372 & 1.000 & .381 & -.446 & .082 & -.299 \\
\hline & LEV_PO & .410 & -.148 & -.735 & -.149 & .148 & -.030 & -.141 & .381 & 1.000 & -.447 & .071 & -.018 \\
\hline & LIK_PO & .007 & -.002 & -.005 & -.026 & -.001 & -.003 & -.311 & -.446 & -.447 & 1.000 & .031 & .093 \\
\hline
\end{tabular}


Prita Utami., Maria M. Ratna Sari, dan I. B. Putra Astika. Kemampuan Prior Opinion....

\begin{tabular}{|c|c|c|c|c|c|c|c|c|c|c|c|c|}
\hline PP_PO & .011 & -.023 & .027 & -.004 & -.136 & -.016 & .396 & .082 & .071 & .031 & 1.000 & -.384 \\
\hline TAT_PO & .328 & .057 & -.017 & -.053 & -.049 & -.421 & -.816 & -.299 & -.018 & .093 & -.384 & 1.000 \\
\hline
\end{tabular}

Sumber : Hasil Penelitian

Koefisien determinasi diuji dengan tujuan agar dapat mengetahui mengenai bagaimana kuat-lemahnya hubungan anatra variabel bebas dan variabel terikat. Besarnya nilai koefisien determinasi dapat dilihat dari Nagelkerke $R$ Square $\left(\mathrm{R}^{2}\right)$, yang digunakan untuk menilai bagaimana kemampuan independen dapat menjelaskan dan memberikan pengaruh terhadap variabel dependen (Ghozali, 2006). Adapun hasil pengujiannya disajikan dalam Tabel 6.

\section{Tabel 6.}

Hasil Pengujian Koefisien Determinasi

\begin{tabular}{lrrrr}
\hline \multirow{2}{*}{ Step } & $\mathbf{- 2}$ Log likelihood & $\begin{array}{c}\text { Cox \& } \\
\text { Snell R } \\
\text { Square }\end{array}$ & \multicolumn{2}{c}{$\begin{array}{c}\text { Nagelkerke R } \\
\text { Square }\end{array}$} \\
\hline 1 & $169,691^{\text {a }}$ & .248 & .506 \\
\hline Sumber: Hasil Penelitian & & &
\end{tabular}

Variasi variabel ROA (profitabilitas), DAR (leverage), likuiditas (LIK), pertumbuhan penjualan (PP), rasio aktivitas (TAT), prior opinion (PO), interaksi profitabilitas dengan prior opinion (ROA*PO), interaksi leverage dengan prior opinion (DAR*PO),interaksi likuiditas dengan prior opinion (LIK*PO), interaksi pertumbuhan perusahaan dengan prior opinion $(\mathrm{PP} * \mathrm{PO})$, dan interaksi rasio aktivitas dengan prior opinion (TAT*PO) mampu menjelaskan variasi sebesar $50,6 \%$.

Hasil pengujian mengenai matrik klasifikasi memudahkan dalam menggambarkan kondisi going concern pada auditee. Matrik klasifikasi dinilai dengan menggunakan angka pada Classification Table. Adapun hasilnya disajikan dalam tabel berikut. 
Tabel 7.

Hasil Pengujian Matrik Klasifikasi

\begin{tabular}{|c|c|c|c|c|c|}
\hline \multirow{3}{*}{\multicolumn{2}{|c|}{ Observed }} & & \multicolumn{3}{|c|}{ Predicted } \\
\hline & & & \multicolumn{2}{|c|}{ OGC } & \multirow{2}{*}{$\begin{array}{c}\text { Percentage } \\
\text { Correct }\end{array}$} \\
\hline & & &, 00 & 1,00 & \\
\hline \multirow[t]{3}{*}{ Step 0} & \multirow[t]{2}{*}{ OGC } & ,00 & 392 & 0 & 100.0 \\
\hline & & 1,00 & 46 & 0 & 0.0 \\
\hline & \multicolumn{2}{|c|}{ Overall Percentage } & & & 89.5 \\
\hline
\end{tabular}

Hipotesis yang telah disusun sebelumnya diuji menggunakan model regresi logistik dengan tingkat kepercayaan $95 \%$ atau taraf signifikasi $5 \%(\alpha=0,05)$. Diterima atau ditolaknya hipotesis dapat dilihat melalui estimasi paramater di dalam Variables in The Equation. Adapun hasilnya adalah sebagai berikut.

Tabel 8.

Hasil Pengujian Hipotesis

\begin{tabular}{|c|c|c|c|c|c|c|c|c|c|}
\hline & & B & S.E. & Wald & df & Sig. & $\operatorname{Exp}(B)$ & $\begin{array}{r}95 \% \\
\mathbf{E}\end{array}$ & $\begin{array}{l}\text { I.for } \\
\text { B) }\end{array}$ \\
\hline & & & & & & & & Lower & Upper \\
\hline Step $1^{\mathrm{a}}$ & ROA & -.150 & .040 & 14.127 & 1 & .000 & .861 & .796 & .931 \\
\hline & LEV & .879 & .616 & 2.038 & 1 & .153 & 2.409 & .720 & 8.057 \\
\hline & LIK & .000 & .000 & 2.751 & 1 & .097 & 1.000 & 1.000 & 1.000 \\
\hline & $\mathrm{PP}$ & .083 & .283 & .085 & 1 & .770 & 1.086 & .624 & 1.892 \\
\hline & TAT & -.705 & .566 & 1.551 & 1 & .213 & .494 & .163 & 1.498 \\
\hline & PO & -.256 & 1.659 & .024 & 1 & .877 & .774 & .030 & 19.980 \\
\hline & ROA_PO & -.519 & .246 & 4.475 & 1 & .034 & .595 & .368 & .963 \\
\hline & LEV_PO & -1.303 & .838 & 2.415 & 1 & .120 & .272 & .053 & 1.405 \\
\hline & LIK_PO & .002 & .002 & .901 & 1 & .343 & 1.002 & .998 & 1.006 \\
\hline & PP_PO & -1.603 & 2.088 & .589 & 1 & .443 & .201 & .003 & 12.063 \\
\hline & TAT_PO & 1.468 & 1.346 & 1.190 & 1 & .275 & 4.341 & .310 & 60.715 \\
\hline & Constant & -1.917 & .719 & 7.111 & 1 & .008 & .147 & & \\
\hline
\end{tabular}

Sumber : Hasil Penelitian

Berdasarkan Tabel 8, nilai estimasi parameter dalam Variables in The Equation yang dapat dibentuk oleh model regresi adalah sebagai berikut.

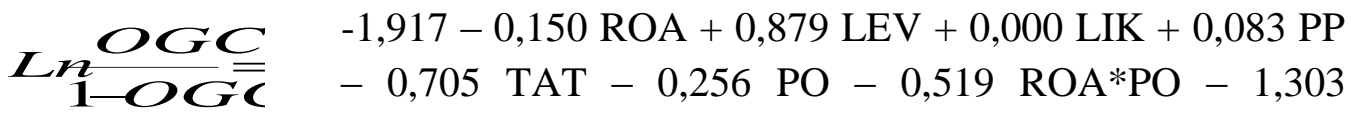


Prita Utami., Maria M. Ratna Sari, dan I. B. Putra Astika. Kemampuan Prior Opinion....

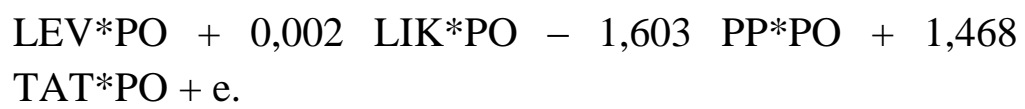

Hasil dari uji hipotesis pertama menunjukkan bahwa nilai koefisien beta $\left(b_{5}\right)$ adalah $-0,519$ dengan nilai signifikansi sebesar 0,034 dimana nilai ini lebih kecil dari $\alpha=0,05$ yang berarti $\mathrm{H}_{1}$ diterima, dan menunjukkan bahwa terdapat moderasi prior opinion dan memperlemah pengaruh profitabilitas yang diproksikan dengan ROA pada pemberian opini audit going concern. Hasil ini membuktikan bahwa terdapat moderasi prior opinion dan memperlemah pengaruh profitabilitas yang diproksikan dengan ROA pada pemberian opini audit going concern. Hasil yang serupa juga ditunjukkan oleh hasil penelitian dari Kartika (2012) serta Veri dan Erni (2010). Jika di tahun sebelumnya perusahaan tidak memperoleh opini audit going concern dikarenakan rasio profitabilitas yang dimiliki perusahaan adalah baik, maka di tahun selanjutnya auditor akan kembali mengeluarkan opini yang sama sesuai dengan kondisi rasio profitabilitas perusahaan dengan diperkuat prior opinion / opini audit mereka di tahun sebelumnya.

Hasil uji hipotesis kedua pada penelitian ini menunjukkan bahwa nilai koefisien beta $\left(b_{5}\right)$ adalah $-1,303$ memiliki tingkat signifikansi 0,120 dimana nilai ini lebih besar dari $\alpha=0,05$ yang berarti bahwa $\mathrm{H}_{2}$ ditolak dan menunjukkan bahwa tidak terdapat moderasi prior opinion terhadap pengaruh leverage yang diproksikan dengan DAR pada pemberian opini audit going concern. Sejalan dengan penelitian Eko (2006) yang menyatakan bahwa rasio leverage tidak memiliki berpengaruh signifikan terhadap opini audit going concern. 
Jika sebelumnya perusahaan diberikan opini audit going concern terkait dengan kondisi keuangan yang memburuk diakibatkan oleh rasio leverage yang tinggi, tidak dapat dipastikan di tahun selanjutnya perusahaan juga kembali memperoleh opini audit going concern. Semua hal ini tergantung pada usahausaha dan strategi yang dilakukan perusahaan dalam menyikapi setiap permasalahan yang timbul di tahun sebelumnya. Apabila perusahaan berusaha dan mampu memperbaiki kondisi keuangannya dengan memiliki rasio leverage yang rendah maka opini audit going concern tidak akan diberikan di tahun selanjutnya. Jadi menurut hasil penelitian ini prior opinion belum mampu memperkuat pemberian opini audit di tahun sebelumnya, dengan tetap memperhatikan upayaupaya perusahaan baik untuk mempertahankan kondisi yang sudah baik maupun mengurangi atau menghilangkan kondisi buruk perusahaan.

Hasil pengujian atas hipotesis ketiga menunjukkan bahwa nilai koefisien beta $\left(b_{5}\right)$ adalah 0,002 memiliki tingkat signifikansi 0,343 dimana nilai ini lebih besar dari $\alpha=0,05$ yang berarti $\mathrm{H}_{3}$ ditolak, dan menunjukkan bahwa prior opinion tidak bisa memoderasi pengaruh likuiditas pada pemberian opini audit going concern.

Hasil atas pengujian hipotesis ketiga ini mendukung penelitian yang dilakukan oleh Veri \& Erni (2010) dimana rasio likuiditas memiliki pengaruh negatif terhadap pemberian opini audit going concern, dan disimpulkan bahwa perusahaan dengan current ratio yang rendah menunjukkan kemampuan likuiditas rendah dan perusahaan yang hanya memiliki sedikit aktiva yang akan digunakan untuk memenuhi kewajiban jangka pendek memiliki rasio likuiditas yang tinggi 
Prita Utami., Maria M. Ratna Sari, dan I. B. Putra Astika. Kemampuan Prior Opinion....

dalam keberlangsungan perusahaan. Dari penelitian ini dapat digambarkan bahwa current ratio tidak memberikan pengaruh bagi pihak auditor memberikan opini audit going concern. Penyebabnya adalah karena auditor selain memperhatikan cara perusahaan untuk memenuhi kewajiban yaitu kewajiban jangka pendek, namun juga memperhatikan keseluruhan kemampuan perusahaan.

Hasil pengujian atas hipotesis keempat menunjukkan bahwa nilai koefisien beta (b5) adalah -1,603 memiliki nilai signifikansi 0,443 dimana nilai ini lebih besar dari $\alpha=0,05$ yang berarti $\mathrm{H}_{4}$ ditolak, dan menunjukkan bahwa pengaruh pertumbuhan perusahaan pada pemberian opini audit going concern tidak mampu dimoderasi oleh prior opinion. Sejalan dengan penelitian Ekasari (2011), dimana auditor tidak sepenuhnya memberikan opini yang didasarkan pada opini audit di tahun sebelumnya untuk mengeluarkan kembali opini audit going concern.

Hal ini menunjukkan bahwa prior opinion belum bisa menjadi patokan di untuk tahun selanjutnya. Jika pada tahun sebelumnya perusahaan memperoleh opini audit going concern disebabkan oleh faktor pertumbuhan perusahaan yang buruk, maka di tahun selanjutnya auditor belum tentu akan kembali memberikan opini yang sama dan akan disesuaikan kembali dengan kondisi rasio pertumbuhan perusahaan saat itu.

Hasil penelitian Soliyah (2014) juga menemukan bahwa pertumbuhan perusahaan tidak berpengaruh terhadap pemberian opini audit going concern. Pertumbuhan perusahaan yang dilihat dari pertumbuhan aktiva tahunan tidak menjadi ukuran perusahaan mendapatkan opini audit going concern. Aset 
perusahaan bertambah, tetapi penjualan perusahaan tetap atau menurun, dan kewajiban perusahaan semakin bertambah tidak akan membuat keadaan perusahaan menjadi lebih baik dan mengurangi kemungkinan untuk mendapatkan opini audit going concern. Hasil pengujian hipotesis keempat dari penelitian ini menggambarkan bahwa pertumbuhan penjualan yang positif tidak bisa diasumsikan akan secara otomatis berpengaruh positif terhadap laba yang diperoleh perusahaan. Peningkatan beban operasional juga harus diperhitungkan, peningkatan penjualan yang lebih rendah dari beban operasional akan menghasilkan laba bersih yang negatif dan akan berkibat pada menurunnya saldo laba ditahan perusahaan.

Pertumbuhan perusahaan yang dilihat dari pertumbuhan aktiva tahunan tidak menjadi ukuran perusahaan mendapatkan opini audit going concern. Aset perusahaan bertambah, tetapi penjualan perusahaan tetap atau menurun, dan kewajiban perusahaan semakin bertambah tidak akan membuat keadaan perusahaan menjadi lebih baik dan mengurangi kemungkinan untuk mendapatkan opini audit going concern. Hasil ini menggambarkan bahwa pertumbuhan penjualan yang positif tidak bisa diasumsikan akan secara otomatis berpengaruh positif terhadap laba yang diperoleh perusahaan. Peningkatan beban operasional juga harus diperhitungkan, peningkatan penjualan yang lebih rendah dari beban operasional akan menghasilkan laba bersih yang negatif dan akan berkibat pada menurunnya saldo laba ditahan perusahaan.

Hasil pengujian atas hipotesis kelima menunjukkan bahwa nilai koefisien beta (b5) adalah 1,468 memiliki tingkat signifikansi 0,275 dimana nilai ini lebih 
Prita Utami., Maria M. Ratna Sari, dan I. B. Putra Astika. Kemampuan Prior Opinion....

besar dari $\alpha=0,05$ yang berarti bahwa $\mathrm{H}_{5}$ ditolak dan menunjukkan bahwa tidak terdapat moderasi prior opinion terhadap pengaruh rasio aktivitas yang diproksikan dengan TAT pada pemberian opini audit going concern. Penelitian Ekasari (2011) menyatakan hasil pemberian kembali opini going concern tidak selalu berpatokan pada opini going concern yang diperoleh di tahun sebelumnya saja, tetapi lebih ditujukan pada dampak yang dihasilkan oleh penerbitan opini going concern itu. Hal ini menunjukkan bahwa prior opinion belum bisa menjadi patokan di dalam pemberian opini audit di tahun selanjutnya. Apabila di tahun sebelumnya perusahaan memperoleh opini audit going concern disebabkan oleh faktor rasio aktivitas yang buruk, maka di tahun selanjutnya auditor belum tentu akan kembali memberikan opini yang sama dan akan disesuaikan kembali dengan kondisi rasio rasio aktivitas perusahaan saat itu.

\section{SIMPULAN DAN SARAN}

Dari hasil penelitian ini dapat disimpulkan bahwa hanya profitabilitas yang mampu dimoderasi dan prior opinion memperlemah pengaruh profitabilitas terhadap pemberian opini audit going concern. Sedangkan tidak terdapat moderasi prior opinion terhadap leverage, likuiditas, pertumbuhan perusahaan, dan rasio aktivitas pada pemberian opini audit going concern.

Saran yang dapat diberikan yaitu 1) Auditor didalam memberikan opini kepada perusahaan tidak serta merta memandang prior opinion sebagai tolak ukur pemberian opini. Hal ini perlu dipertahankan dan dapat dijadikan dasar bagi auditor lainnya, disebabkan oleh kondisi perusahaan bisa saja berubah dalam periode waktu berjalan disebabkan oleh peningkatan omset, perubahan pangsa 
pasar, cash flow perusahaan dan sebagainya, 2) Peneliti selanjutnya bisa merancang variabel pemoderasi yang lebih tepat karena variabel prior opinion ternyata tidak mampu memoderasi pengaruh leverage, likuiditas, pertumbuhan perusahaan, dan rasio aktivitas terhadap pemberian opini audit going concern.. 3) Sebaiknya penelitian diperluas memakai seluruh perusahaan yang terdaftar di BEI. 4) Nilai koefisien determinasi (Nagelkerke $R$ Square) sebesar 50,6 \% dimana artinya masih ada sisa sejumlah 49,4 \% yang dijelaskan variabel lain diluar model. Jadi masih penelitian selanjutnya sebaiknya mempertimbangkan pengembangan penelitian ini dengan menambahkan variabel lain seperti ROI, DER, ukuran perusahaan, kondisi keuangan perusahaan, serta variabel lainnya yang mungkin terkait.

\section{REFERENSI}

Altman, E. I. 1968. Financial Ratios, Discriminant Analysis and the Prediction of Corporate Bankruptcy. Journal of Finance, September: 589- 609.

Amilin dan Ady Indrawan. 2008. “Analisis Penilaian Going Concern Perusahaan dan Opini Audit oleh Kap Big Four Dengan Kap Non Big Four (Studi pada Emiten di Bursa Efek Indonesia)". Jurnal Ekonomi: Analisis Ilmiah Ekonomi, Manajemen, Keuangan dan Akuntansi, Vol. 18, No. 2.

Brigham, Eugene F and Joel F. Houston, 2006. Dasar-Dasar Manajemen Keuangan, alih bahasa Ali Akbar Yulianto, Buku satu, Edisi sepuluh, PT. Salemba Empat, Jakarta.

Behn, Bruce K., Steven E. Kaplan, and Kip R. Krumwiede. 2001. Further Evidence on the Auditor's Going-Concern Report: The Influence of Management Plans. Auditing: A Journal of Practice \& Theory. Vol. 20, No.1: 13-18.

Carcello, Joseph V., and Terry L. Neal. 2000. Audit Committee Composition and Auditor Reporting. The Accounting Review, Vol.75, No.4 October 2000 :453467.

Chen, Kevin C. W., and Bryan K. Church. 1992. Default on Debt Obligations and the Issuance of Opini Going-Concern Opinions. Auditing: A Journal of 
Prita Utami., Maria M. Ratna Sari, dan I. B. Putra Astika. Kemampuan Prior Opinion....

Practice \& Theory. Vol. 11, No. 2: 30-49.

Clarkson, Peter M., and Dan A. Simunic. 1994. The Association between Audit Quality, Retained Ownership, and Firm-Specific Risk in U.S. vs. Canadian IPO Markets. Journal of Accounting and Economics. Vol. 17: 207-228.

Ekasari, Dina. 2012. Opini Audit Going Concern Kajian Berdasarkan Prediksi Kebangkrutan, Deb Default, Dan Opini Audit Tahun Sebelumnya. Jurnal Ekonomi Universitas Gunadarma.

Eko, Budi Setyarno dan Indira Januati. 2006. "Pengaruh Kualitas Audit, Kondisi Keuangan Perusahaan, Opini Audit Tahun Sebelumnya, Pertumbuhan Perusahaan Terhadap Opini Audit Going Concern”. Simposium Nasional Akuntansi 9 Padang.

Elder, R. J., M. S. Beasley, A. A. Arens, \& A.A. Jusuf. 2011. Jasa Audit dan Assurance: Pendekatan Terpadu (Adaptasi Indonesia) Buku 1. Salemba Empat. Jakarta.

Erly Sherlita dan Elok Tika Puspita. 2012. "The Effect of Financial Ratios, Prior Audit Opinion, and Growth on The Auditors Going Concern Opinion. Proceeding The $13^{\text {th }}$ Malaysia Indonesia Conference on Economics, Management and Accounting (MICEMA).

Fabozzi, Frank J. 2000. Manajemen Investasi. Buku Dua, Salemba Empat, Pearson Education Asia Pte. Ltd. Prentice Hall.

Fanny, Margaretta dan Saputra, S. 2005. “Opini Audit Going Concern : Kajian Berdasarkan Model Prediksi Kebangkrutan, Pertumbuhan Perusahaan, Dan Reputasi Kantor Akuntan Publik (Studi Pada Emiten Bursa Efek Jakarta)". Simposium Nasional Akuntansi VIII. Solo 15-16 September 2005.

Foroghi, Daruosh. 2012. "Audit Firm Size and Going Concern Reporting Accuracy", Interdiciplinary Journalof Contemporary Research In Business, Vol. 3, No. 9.

Govindarajan, V. 1986. "Impact of Participation in the Budgetary Process on Managerial Attitudes and Performance: Universalistic and Contingency Perspective". Decision Science 17. Hal. 496-516.

Hari Govind Mishra, Piyush Kumar Sinha \& Surabhi Koul. 2014. "Buying Impulsive Trait An Effective Moderator for Shopping Emotions and Perceived Risk". Journal of Management Research, Vol. 14, No 2, April-June 2014, pp. 109-220.

Ikatan Akuntan Indonesia. 2011. Standar Profesional Akuntan Publik. Jakarta. Salemba Empat. 
Imam Ghozali. 2011. Aplikasi Analisis Multivariate dengan Program SPSS. Semarang: Badan Penerbit UNDIP.

Indonesian Capital Market Directory (ICMD) - Bursa Efek Indonesia, 20102015, Jakarta.

Ishaya John Dabari \& Siti Zabedah Saidin. 2015. A Moderating Role of Board Characteristics on Enterprise Risk Management Implementation: Evidence from The Nigerian Banking Sector. International Journal of Economics and financial Issues, 2016, 6 (S4) 96-103.

Januarti, Indira, dan Ella Fitrianasari. 2008. “Analisis Rasio Keuangan dan Rasio Non Keuangan yang Mempengaruhi Auditor dalam memberikan Opini Audit Going Concern pada Auditee". Jurnal MAKSI, Vol. 8, No. 1.

Jensen, M.C and Meckling, W.H. 1976. "Theory Of The Firm, Managerial Behaviour, Agency Cost \& Ownership Structure". Journal of Financial Economics, Vol. 3, October. Pp 305-360.

Kartika, Andi. 2012. "Pengaruh Kondisi Keuangan dan Non Keuangan Terhadap Penerimaan Opini Going Concern pada Perusahaan Manufaktur di BEI".

Dinamika Akuntansi, Keuangan dan Perbankan, pg. 25-40.

Khalatbari, Abdossamad, Ramezanpour, Ismail \& Haghdoost, Jalal. 2013. "Studying The Relationship of Earning Quality and Audit Delay in Accepted Companies in Tehran Securities". International Research Journal of Applied and Basic Sciences, Vol. 6, No.5, pp.549-555.

Kristiana, I. 2012. Pengaruh Ukuran Perusahaan, Profitabilitas, Likuiditas, Pertumbuhan Perusahaan Terhadap Opini Audit Going Concern. Jurnal Universitas Katolik Widya Mandala Surabaya, Vol. 1, No. 1.

Masyitoh, Oni Currie and Desi Adhariani. 2010. The Analysis of Determinants of Going concern Audit Report. Journal of Modern Accounting and Auditing. Vol. 6, No.4: 26-37.

Nursasi Enggar, Evi Maria. 2015. "Pengaruh Audit Tenure, Opinion Shopping, Leverage, dan Pertumbuhan Perusahaan Terhadap Penerimaan Opini Audit Going Concern Pada Perusahaan Perbankan dan Pembiayaan Yang Go Public di Bursa Efek Indonesia'. Jurnal JIBEKA, Volume 9 Nomor 1.

O’Reilly, Dennis M. 2010. “Do Investors Percieve The Going Concern Opinion As Useful For Pricing Stocks?". Journal Department Of Accounting, College Business, East Carolina University, Greenville, North Carolina, USA.

Petronela, Thio. 2004. Pertimbangan Going Concern Perusahaan Dalam 
Prita Utami., Maria M. Ratna Sari, dan I. B. Putra Astika. Kemampuan Prior Opinion....

Pemberian Opini audit. Jurnal Balance. 47-55

Pourali, Mohammad Reza, Jozi, Mahshid, Rostami, Keramatollah Heydari, Taherpour, Ghollam Reza \& Niazi, Faramarz. 2013. "Investigation of Effective Factors in Audit Delay: Evidence from Tehran Stock Exchange (TSE)", Research Journal of Applied Sciences, Engineering and Technology, Vol. 5, No.2, pp.405-410.

Praptitorini, Mirna Dyah dan Indira Januarti. 2007. Analisis Pengaruh Kualitas Audit, Debt Default, dan Opinion Shopping terhadap Penerimaan Opini Going Concern. Simposium Nasional Akuntansi X. Makassar: 26-28 Juli.

Rudyawan, Arry Pratama dan I Dewa Nyoman Badera. 2008. Opini Audit Going Concern : Kajian Berdasarkan Model Prediksi Kebangkrutan, Pertumbuhan Perusahaan, Leverage, Dan Reputasi Auditor. Jurnal Akuntansi dan Bisnis, Vol. 4, 2 Juli 2009.

Sari, Kumala. 2012. Analisi Pengaruh Audit Tenure, Reputasi KAP, Disclosure, Ukuran Perusahaan dan Likuiditas Terhadap Penerimaan Opini Audit Going Concern (Studi Empiris pada Perusahaan Manufaktur yang Listing di BEI tahun 2005-2010). Jurnal Ekonomi Universitas Diponegoro, Semarang.

Setyarno, E. B., Januarti, I, dan Faisal. 2006. Pengaruh Kualitas Audit, Kondisi Keuangan Perusahaan, Opini Audit Tahun Sebelumnya, Pertumbuhan Perusahaan Terhadap Opini Audit Going Concern. Simposium Nasional Akuntansi IX, Padang.

Sugiyono. 2014. Metode Penelitian Kuantitatif, Kualitatif dan Kombinasi (Mixed Methods). Bandung: Alfabeta.

Tucker, Robert R., Ella Mae Matsumura, dan K. R. Subramanyam. 2003. Going Concern Judgements: An Experimental Test of The Self-fulfilling Prophecy and Forecast Accuracy. Available at: http://www.ssrn.com. (accessed 15 Desember 2014).

Veri Anang Putra \& Erni Suryandari. 2010. Analisis Rasio Keuangan dan Faktor Non Keuangan Yang mempengaruhi Auditor dalam memberikan Opini Audit Going Concern pada Auditee. Jurnal Akuntansi dan Investasi, Vol. 11 No.1 Halaman 53-67. Universitas Muhammadiyah Yogyakarta.

Weston, Fred, J dan Thomas, E Copeland. (2010). Manajemen Keuangan Jilid 2. Jakarta : Binarupa Aksara Publisher.

Widyantari, Ayu Putri. 2011. “Opini audit Going Concern dan Faktor-faktor yang Memengaruhi (Studi pada Perusahaan Manufaktur di Bursa Efek Indonesia”. Tesis S-2 Program Pasca Sarjana Universitas Udayana. Denpasar. 